\title{
Activity of soil enzymes in constructed wetlands treated with swine wastewater
}

Ramgopal Baddam, Gudigopuram B. Reddy, Charles Raczkowski and Johnsely S. Cyrus

Department of Natural Resources and Environmental Design, North Carolina A\&T State University, Greensboro, NC 27411, USA

\section{Corresponding author: Johnsely S. Cyrus}

Department of Natural Resources and Environmental Design

North Carolina A\&T State University

1601 E Market Street, Greensboro, NC 27411, USA

Email: jscyrus@ncat.edu

Tel: 001-3362854855

Fax: 001-336 3347844 


\begin{abstract}
Continuous application of swine wastewater from lagoons to agricultural land can pose surface and groundwater pollution. Constructed wetland $(\mathrm{CW})$ is an alternate to the lagoon spray field system that reduces the nutrients concentration. One of the biological processes in $\mathrm{CW}$ is enzymatic activity which plays a major role in releasing nutrients from organic substances. The objectives of this research were to investigate the activity of soil enzymes in $\mathrm{CW}$ treated with swine wastewater and to assess the relationship between the enzyme activity and nutrients concentration. One continuous marsh (CM) and one marsh-pond-marsh (MPM) wetland cells were investigated for enzymatic activity. The activities of dehydrogenase, urease, phosphatase, and $\beta$-glucosidase were significantly higher at $0-3 \mathrm{~cm}$ than $6-12 \mathrm{~cm}$ depth. Enzyme activities were higher in marsh soils of CM than pond soils of MPM. There was no significant difference in enzyme activity between inlet and outlet of CM and pond area of MPM. No significant relationship was found between the enzyme activity and nutrient concentration. Urease, phosphatase and arylsulfatase activity were correlated to soil $\mathrm{C}$ and $\mathrm{N}$, whereas, $\beta$ glucosidase activity was correlated to soil C. The results suggest that enzyme activity has aided in detritus decomposition and thus, decreased enzymatic activities may decrease nutrients availability.
\end{abstract}

\title{
Keywords
}

Constructed wetlands, Enzyme activity, Swine wastewater 


\section{Introduction}

North Carolina ranks second in the nation in swine production after Iowa. These swine operations produce large amounts of waste which needs to be disposed properly without creating environmental hazards. Traditionally, the swine operations flush the waste with water into an aerobic or anaerobic lagoon and spread the lagoon wastewater on agricultural fields. However, such practices may impact on surface and ground water quality (Mallin, 2000). Also, continuous application of swine wastewater on land can lead to the accumulation of nitrogen $(\mathrm{N})$ and phosphorus $(\mathrm{P})$ in spray fields. To reduce the contamination of surface and ground water, alternative methods of treating wastewater should be implemented and one of the methods to treat swine waste is the use of constructed wetlands (CWs).

Constructed wetlands provide an efficient ecological system with low maintenance requirements and construction costs to remove nutrients from animal wastewater (Kadlec and Knight, 1996; Hill et al., 1999). Wetlands support large diversity of microbial communities (Dong and Reddy, 2010) which play an important role in nutrients cycling (Wright and Reddy, 2001). Constructed wetlands successfully treat animal wastewater prior to land application and reduce nutrient concentrations applied to crops and pastures (Knight et al., 2000; Reddy et al., 2001). Earlier studies conducted on marsh-pond-marsh (MPM) CWs showed promising results in removing nutrients (Reddy et al., 2001; Hunt et al., 2002; Poach et al., 2004). 
Wetland technology removes excess nutrients from wastewater by the process of sedimentation, adsorption, organic matter accumulation, microbial assimilation, nitrification-denitrification, and ammonia volatilization (Johnstone, 1991; Brix, 1993). One of the biological activities is enzymatic approach related to decomposition processes in wetland sediments (Tabatabai, 1982). Enzyme activity depends on both total microbial biomass and enzyme efficiency. Majority of the soluble soil enzymes originate from soil microorganisms where these enzymes are synthesized, secreted, and, in turn they act as generators of signals to induce further enzymes production by other microbes and plants. Enzyme activity in constructed wetlands is affected by many factors, including biological factors (microbial populations, higher taxa, and fauna), soil factors ( $\mathrm{pH}$, texture, nutrient composition, depth profiles, organic matter content, etc.) and climatic factors ( Kang et al., 1998; Zaman et al., 1999; Duarte et al., 2008; Reboreda and Cacador, 2008). Therefore, it is important to understand extracellular enzymes that relate to decomposition process in CWs which will play a vital role as initiators of organic pollutant removal in treatment wetlands (Allison and Vitousen, 2005; Reddy et al., 2010) and many researchers (Krasnits et al., 2009; Aguilar et al., 2008) have recognized their role in interaction between substrate, wetland plants and microorganisms for wastewater purification.

In this research, we studied the activity of dehydrogenase, urease, phosphatase, and $\beta$ glucosidase activity in constructed wetlands receiving swine wastewater. Urease catalyzes the hydrolysis of urea into carbon dioxide and ammonia. The urea in the 
wastewater originates from swine urine. Phosphatase enzyme catalyzes the organic-P that originates from the indigestible $\mathrm{P}$ excretion by swine into inorganic $-\mathrm{P}$. $\beta$ glucosidase catalyzes the hydrolysis of sugars resulting in the formation of $\beta$-linked monosaccharides and the final product of enzymatic reaction is glucose which is a carbon source for soil microorganisms. Dehydrogenase enzyme oxidizes soil organic matter by transferring electrons and protons from substrates to acceptors and considered as an indicator of microbial activity in soil.

In this study, CWs received nutrients and organic matter from swine wastewater from spring until part of fall and plant residue in winter. Soil enzymes are affected by nutrient loading and available nutrients can potentially decrease their activity (Chrost, 1991; Wetzel, 1991). However, information on enzymatic activity and their relationship to the nutrients concentration in highly nutrient loaded CWs is sparsely available in the literature. Therefore, in order to predict the nutrient loading impact on nutrient removal efficiency, it is important to better understand the enzymes activity in CWs receiving swine wastewater. The objectives of the study were to (i) determine enzymes (Bglucosidase, dehydrogenase, phosphatase, and urease) activity at different soil depths of constructed wetlands treated with swine wastewater, and (ii) relate their nutrients concentration to the enzymes activity.

\section{Materials and methods}

\subsection{Site and wetland cells design}


The experiment was conducted in one continuous marsh (CM) and one marsh-pondmarsh (MPM) cell at the swine research facility of the North Carolina A\&T State University farm in Greensboro, NC, USA using surface flow wetlands in a continuous marsh (CM) and marsh-pond-marsh (MPM) design (Fig 1a) . The 11m wide (W) $\times 40 \mathrm{~m}$ long (L) wetlands were constructed in 1995 (Reddy et al., 2001) and operated since 1998 to treat swine wastewater generated from the university swine farm unit. The CM consisted of $11 \mathrm{~m} \mathrm{~W} \times 40 \mathrm{~m} \mathrm{~L}$, whereas MPM had $11 \mathrm{~m} \mathrm{~W} \times 10 \mathrm{~m} \mathrm{~L}$ as marsh sections at both the influent and effluent ends. The water depth of $0.15 \mathrm{~m}$ was maintained in marshes of CM and MPM. The pond area of MPM had $11 \mathrm{~m} \mathrm{~W} \times 20 \mathrm{~m} \mathrm{~L} \mathrm{x} 0.75 \mathrm{~m}$ water depth. The marsh sections of both wetland cell types were planted with Typha latifolia L. (broadleaf cattail) and Schoenoplectus americanus (American bulrush) (Fig 1b).

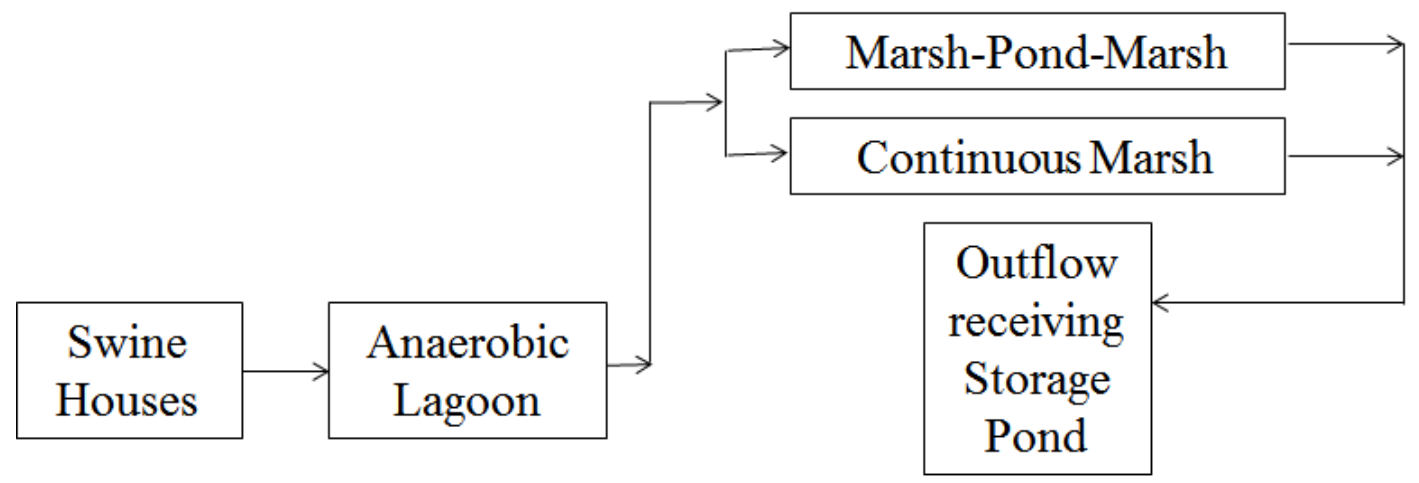

Fig. 1a. Flow path of wastewater from the swine houses to the constructed wetlands. 

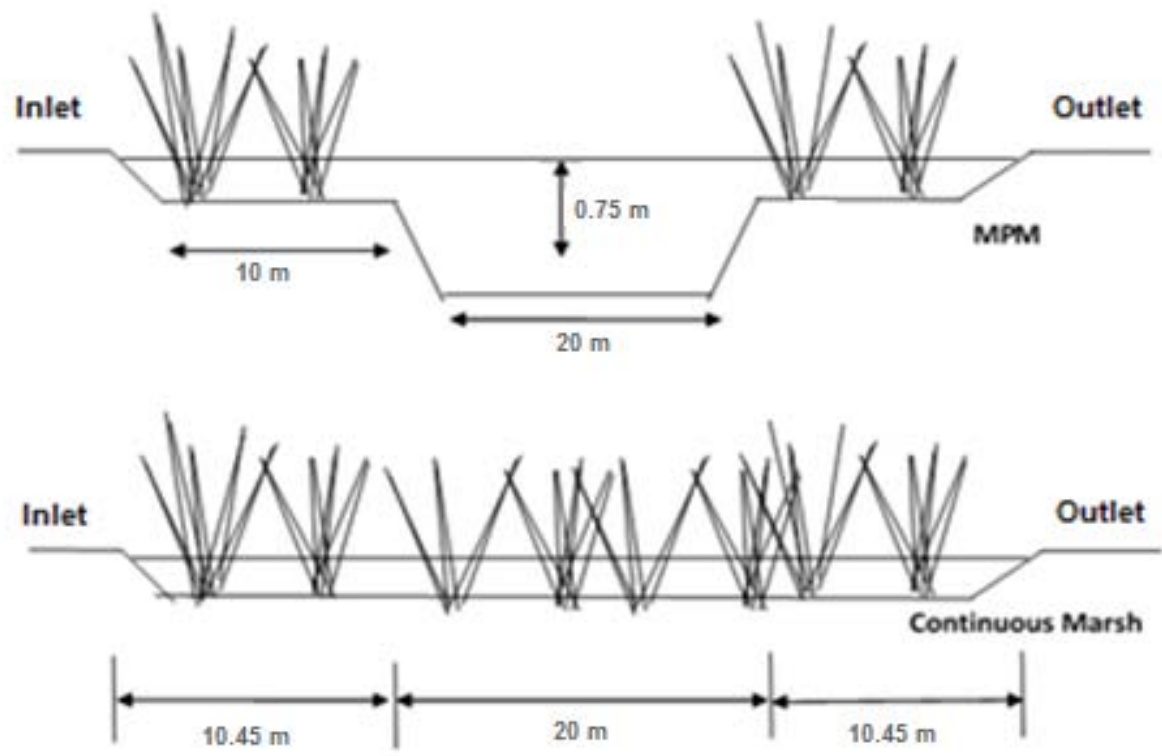

Fig. 1b. Schematic diagram showing continuous marsh (CM), and pond section separates marsh areas in Marsh-Pond-Marsh (MPM) constructed wetlands.

The removal rates of total solids, suspended solids, chemical oxygen demand, and nutrients $(\mathrm{N}$ and $\mathrm{P})$ at different hydraulic loads and retention times of these $\mathrm{CWs}$ were published by Reddy et al., 2001 and Poach et al., 2004 and microbial diversities were elucidated by Dong and Reddy (2010).

\subsection{Soil sampling}

An auger having a diameter of $4.4 \mathrm{~cm}$ was used to collect soil samples from within each of the two marsh areas and from the pond area of the Marsh-Pond-Marsh system. Four 
samples were collected at random locations within each of the three sampling areas (marsh inlet, middle, and marsh outlet) in the continuous marsh system and pond area of MPM system. The 0-12 cm samples were sectioned to $0-3 \mathrm{~cm}, 3-6 \mathrm{~cm}$, and $6-12 \mathrm{~cm}$ soil depths. The sampling procedure resulted in a total of 36 samples per cell (4 samples $\mathrm{x} 3$ locations $\mathrm{x} 3$ depths). We feel that this sampling procedure was sound and the data analysis including measurements of variability demonstrates that the sample numbers were adequate. The wet soil samples were placed in polythene bags, transported in an ice chest to the laboratory, and stored in the refrigerator at $4^{\circ} \mathrm{C}$ for further analysis.

\subsection{Soil analysis procedure}

A soil sub-sample was air dried in the laboratory for two days. The percent moisture of the original wet sample was determined. The air dried soil samples were crushed and sieved through $2.0 \mathrm{~mm}$ mesh to remove any plant or other material, and mixed thoroughly and stored in the refrigerator in plastic bags and used for chemical analysis.

\subsection{Soil analysis}

The $\mathrm{pH}$ of each soil sample was determined using $\mathrm{pH}$ meter (Orion 3 star $\mathrm{pH}$ bench top), Total carbon and nitrogen were determined using a CHN analyzer (Perkin Elmer series 2 model: 2400), Microbial biomass carbon (MBC) was determined using a fumigation extraction procedure (Vance et al., 1987) with $0.5 \mathrm{M} \mathrm{K}_{2} \mathrm{SO}_{4}$ extracts being analyzed using a $\mathrm{CHN}$ analyzer (Perkin Elmer model 2400). Total organic carbon was analyzed with Shimadzu TOC Analyzer (Shimadzu TOC-VCSN). Ammonium $\left(\mathrm{NH}_{4}{ }^{+}\right)$ 
and nitrate $\left(\mathrm{NO}_{3}{ }^{-}\right)$extracted with 1.0 M KCL and orthophosphate $\left(\mathrm{PO}_{4}{ }^{-}\right)$were analyzed using flow injection analyzer (FIA) (Lachat instruments Quick chem. 8500 series 2).

\subsection{Soil enzymes activity assay}

The activity of dehydrogenase, urease, phosphatase, and $\beta$-glucosidase was determined in each soil sample. Urease activity was determined according to the procedure of Klose and Tabatabai (2000). A solution containing $10 \mathrm{~mL}$ phosphate buffer $(\mathrm{pH} 6.7), 0.5 \mathrm{~mL}$ toluene and $10 \mathrm{~mL} 10 \%$ aqueous urea was added to $5 \mathrm{~g}$ soil $(<2 \mathrm{~mm})$, and the mixture was incubated for $48 \mathrm{~h}$ at $37^{\circ} \mathrm{C}$. At the end of incubation period, $20 \mathrm{~mL}$ of $1 \mathrm{M} \mathrm{KCL}$ was added and the culture solution was shaken thoroughly for $30 \mathrm{~min}$ and filtered. The released ammonium $\left(\mathrm{NH}_{4}^{+}\right)$in the filtrate was measured by using FIA (Flow Injection Analyzer) and the urease activity was expressed as $\mathrm{mg} \mathrm{NH}_{4}{ }^{+} \mathrm{kg}^{-1}$ of soil.

Phosphatase activity was determined by using the procedure described by Tabatabai and Bremner, (1969) and Eivazi and Tabatabai (1977). One g of soil $(<2 \mathrm{~mm})$ was placed in a $50 \mathrm{~mL}$ Erlenmeyer flask and $4 \mathrm{~mL}$ of modified universal buffer (MUB) (pH 6.5), 0.25 $\mathrm{mL}$ of toluene and $1 \mathrm{~mL}$ of P-nitro phenol (PNP) solution were added as working substrate for the enzyme and the contents were mixed for a few seconds, covered in a flask and placed in an incubator at $37^{\circ} \mathrm{C}$ for $1 \mathrm{~h}$. After $1 \mathrm{~h}$, it was removed and $1 \mathrm{~mL}$ of $0.5 \mathrm{M} \mathrm{CaCl}_{2}$ and $4 \mathrm{~mL}$ of $0.5 \mathrm{M} \mathrm{NaOH}$ were added and swirled thoroughly for a few seconds and then filtered. The yellow color intensity of the filtrate was measured by using a spectrophotometer at $420 \mathrm{~nm}$. 
$\beta$-glucosidase activity was measured according to the procedure described by Eivazi and Tabatabai (1988). One g of soil was placed in a $50 \mathrm{ml}$ Erlenmeyer flask and $4 \mathrm{~mL}$ MUB (pH 6.0), $0.25 \mathrm{~mL}$ of toluene and $1 \mathrm{~mL}$ of P-nitro phenol $\beta$-D-glucoside (PNG) solution (as substrate) were added and swirled the contents for few seconds and covered the flask with parafilm and placed in an incubator at $37^{\circ} \mathrm{C}$ for $1 \mathrm{~h}$. After $1 \mathrm{~h}$ incubation, parafilm was removed and $1 \mathrm{~mL}$ of $0.5 \mathrm{M} \mathrm{CaCl}_{2}$ and $4 \mathrm{~mL}$ of $0.1 \mathrm{M}$ tris hydroxymethyl amino methane (THAM) buffer at $\mathrm{pH} 12$ were added and swirled thoroughly for few seconds and the soil suspension was filtered through a whatman No.4 filter paper. The yellow color intensity of the filtrate was measured by using a spectrophotometer at 420 $\mathrm{nm}$.

Dehydrogenase activity was determined according to the procedure described by Casida, et al. (1964). Six $\mathrm{g}$ of soil was mixed with $0.07 \mathrm{~g}$ of $\mathrm{CaCO}_{3}, 1 \mathrm{~mL}$ of $3 \%$ aqueous solution of 2, 3,5 Triphenyltetrazolium Chloride (TTC) and $2.5 \mathrm{~mL}$ distilled water. Contents in each tube were mixed, covered with parafilm and placed in an incubator at $37^{\circ} \mathrm{C}$ for $24 \mathrm{~h}$. After $24 \mathrm{~h}$ incubation, parafilm was removed and $10 \mathrm{~mL}$ of methanol was added and shaken for 1 min and solution was filtered through a glass funnel plugged with absorbent cotton in to a $100 \mathrm{~mL}$ volumetric flask. The tube was washed with methanol, quantitatively transferred the soil to the funnel and then additional methanol was added to the funnel until the reddish color disappeared from 
the cotton plug. The filtrate was diluted to $100 \mathrm{~mL}$ and the intensity of the reddish color was measured by using spectrophotometer at a wavelength of $485 \mathrm{~nm}$ against blank.

\subsection{Statistical analysis}

Relationship between enzymatic activities to $\mathrm{TC}, \mathrm{TN}, \mathrm{NH}_{4}{ }^{+}$and $\mathrm{PO}_{4}^{-}$ions were evaluated using linear correlation analysis. Correlation coefficients (r) were presented for all possible pairs of correlations. For each enzyme, mean values and standard errors were used to test differences with depth at each site. Differences between means were tested using paired-sample $T$-tests. The level of significance for all analyses was tested at $P<0.05$.

\section{Results}

\subsection{Soil properties}

The $\mathrm{pH}$ values ranged from 6.6 to 7.8 in the wetlands and $\mathrm{pH}$ values did not differ among the depths and between the two wetland systems (Table 1). However, TC and TN decreased with depth. Except, $\mathrm{NH}_{4}{ }^{+}$, concentrations of $\mathrm{NO}_{3}{ }^{-}$, and $\mathrm{PO}_{4}^{-}$were much higher in 0-3 cm than in the deeper soil depths in both wetlands. In addition, we observed that the nutrient concentration were higher in $\mathrm{CM}$ than in the pond area of MPM.

\section{Table 1}


Chemical Parameters measured in CM and pond area of MPM at three soil depths.

\begin{tabular}{|c|c|c|c|c|c|c|}
\hline \multirow{2}{*}{$\begin{array}{c}\text { Soil } \\
\text { Property }\end{array}$} & \multicolumn{3}{|c|}{$\mathbf{C M}$} & \multicolumn{3}{|c|}{ M-P-M (Pond Area) } \\
\hline & $0-3 \mathrm{~cm}$ & 3-6 cm & $6-12 \mathrm{~cm}$ & $0-3 \mathrm{~cm}$ & $3-6 \mathrm{~cm}$ & 6-12 cm \\
\hline $\mathrm{pH}$ & $6.64 \pm 0.12$ & $6.73 \pm 0.13$ & $6.91 \pm 0.24$ & $7.88 \pm 0.12$ & $7.59 \pm 0.20$ & $7.57 \pm 0.18$ \\
\hline $\mathrm{TC}$ & $13558 \pm 6175$ & $8800 \pm 2326$ & $7500 \pm 2055$ & $7025 \pm 4945$ & $5925 \pm 4684$ & $4325 \pm 2117$ \\
\hline $\mathrm{TN}$ & $1375 \pm 685$ & $875 \pm 205$ & $733 \pm 187$ & $950 \pm 102$ & $666 \pm 152$ & $650 \pm 70$ \\
\hline $\mathrm{NH}_{4}^{+}$ & $24.84 \pm 42$ & $12.45 \pm 21$ & $3.62 \pm 3$ & $45.17 \pm 10$ & $40.40 \pm 19$ & $56.45 \pm 37$ \\
\hline $\mathrm{NO}_{3}^{-}$ & $7.90 \pm 13.70$ & $2.20 \pm 2.60$ & $2.80 \pm 4.00$ & $0.40 \pm 0.50$ & $0.10 \pm 0.07$ & $0.08 \pm 0.09$ \\
\hline $\mathrm{PO}_{4}^{-2}$ & $408 \pm 143$ & $237 \pm 128$ & $81 \pm 80$ & $183 \pm 83$ & $92 \pm 102$ & $34 \pm 31$ \\
\hline $\operatorname{Org} \mathrm{N}$ & $1342 \pm 646$ & $860 \pm 197$ & $726 \pm 183$ & $904 \pm 237$ & $625 \pm 246$ & $593 \pm 262$ \\
\hline
\end{tabular}

\subsection{Urease activity}

Urease activity in CM and MPM decreased with increasing soil depth (Fig 2). In CM system, urease activity significantly decreased between $0-3$ and 6-12 $\mathrm{cm}$ depths at both inlet and outlet areas. 


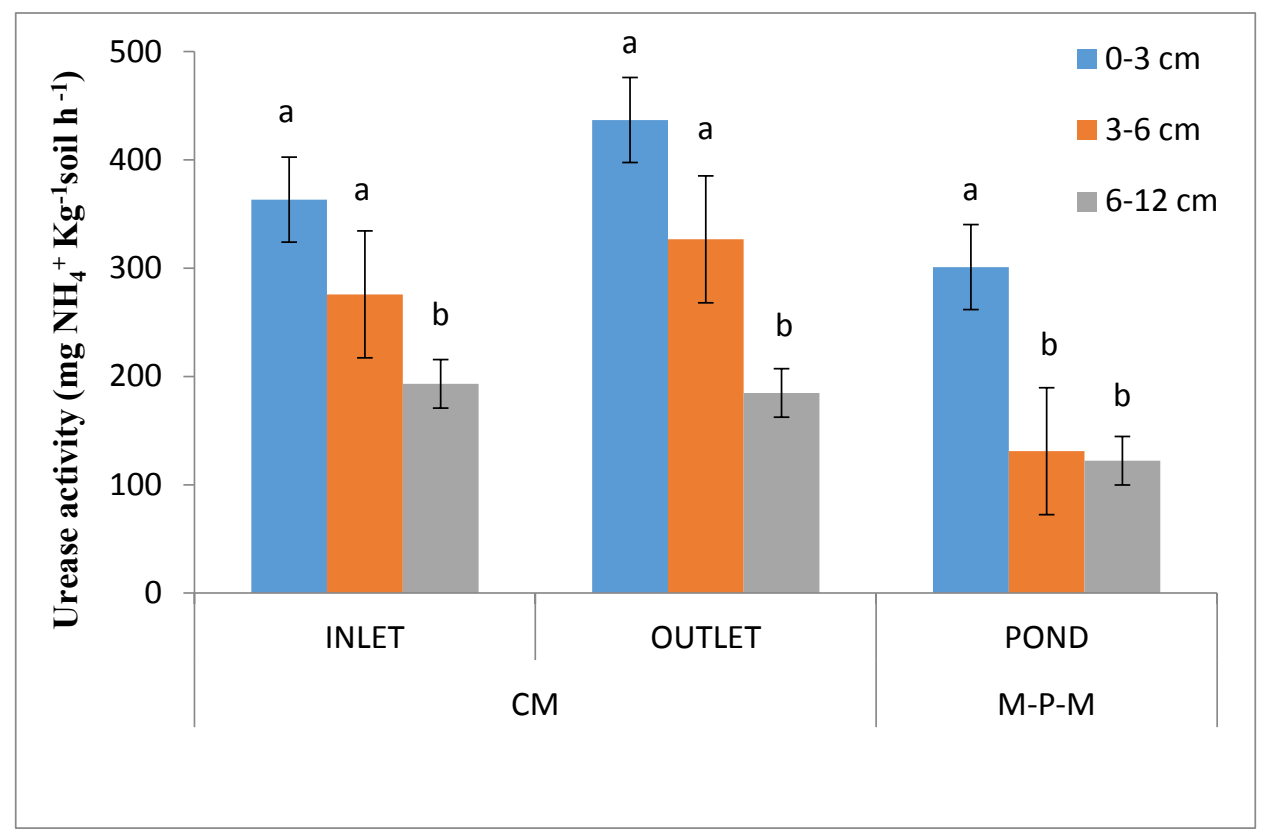

Fig. 2. Urease activity in inlet and outlet areas at different soil depths in the Continuous marsh (CM) and pond area of Marsh pond marsh (MPM) constructed wetlands (mean \pm $\mathrm{SE}, \mathrm{n}=4)$.

Note: Means having the same letters in common are not significantly different at the 5\% level of probability for each site at different soil depths of CM and MPM as determined from t-test pair comparison.

The least enzymatic activity $\left(<200 \mathrm{mg} \mathrm{Kg}^{-1}\right.$ soil) was observed at 6-12 $\mathrm{cm}$ depth in both wetland systems. In CM, the activity of urease increased ( 363 to $436 \mathrm{mg} \mathrm{Kg}^{-1} \mathrm{~h}^{-1}$ at $0-3$ $\mathrm{cm}$ depth) at the inlet area and decreased at the outlet area (280 to $330 \mathrm{mg} \mathrm{Kg}^{-1} \mathrm{~h}^{-1}$ at 3$6 \mathrm{~cm})$. A significant $(P<0.05)$ difference in enzyme activity was not found between inlet and outlet areas in $\mathrm{CM}$ (Table 2). Urease activity depends on the availability of $\mathrm{NH}_{4}{ }^{+}$in the inlet and the outlet areas of the CM wetland. In comparison to MPM pond area, 
urease activity was higher in $\mathrm{CM}$ but the difference was not significant $(P<0.05)$. In both the wetlands, urease activity was higher as compared to other four enzymes studied.

\section{Table 2}

Enzyme activity (mg Kg ${ }^{-1}$ soil h$^{-1}$ ) in the inlet and outlet areas of Continuous marsh (CM) wetland cell.

\begin{tabular}{lcc}
\hline Enzymes & Inlet $\dagger$ & Outlet $\dagger$ \\
\hline Urease & $948^{\mathrm{a}}$ & $832^{\mathrm{a}}$ \\
\hline Phosphatase & $119^{\mathrm{a}}$ & $91^{\mathrm{a}}$ \\
\hline$\beta$-glucosidase & $144^{\mathrm{a}}$ & $143^{\mathrm{a}}$ \\
\hline Dehydrogenase & $9^{\mathrm{a}}$ & $33^{\mathrm{a}}$ \\
\hline
\end{tabular}

Note: + Means having the same letters in common are not significantly different at the 5\% level of probability for inlet and outlet areas of CM as determined from t-test pair comparison.

\subsection{Phosphatase activity}

Phosphatase activity in CM and pond area of MPM was higher in 0-3 cm depth than the other two depths (Fig 3). Inlet area of CM soil samples showed significantly decreased phosphatase activity between 0-3 \& 3-6 cm and 0-3 \& 6-12 cm depth, whereas, similar trend was not observed in the outlet area of the wetland. In pond area, phosphatase activity at $0-3 \mathrm{~cm}$ depth was significantly higher $\left(312 \mathrm{mg} \mathrm{Kg}^{-1} \mathrm{~h}^{-1}\right)$ than the enzyme 
activity (130 mg $\left.\mathrm{Kg}^{-1} \mathrm{~h}^{-1}\right)$ at lower depths. Phosphatase activity was significantly $(P<0.05)$ higher in marsh areas of $\mathrm{CM}$, than in the pond area of MPM. Phosphatase activity showed no significant difference between inlet and outlet area of CM (Table 2).

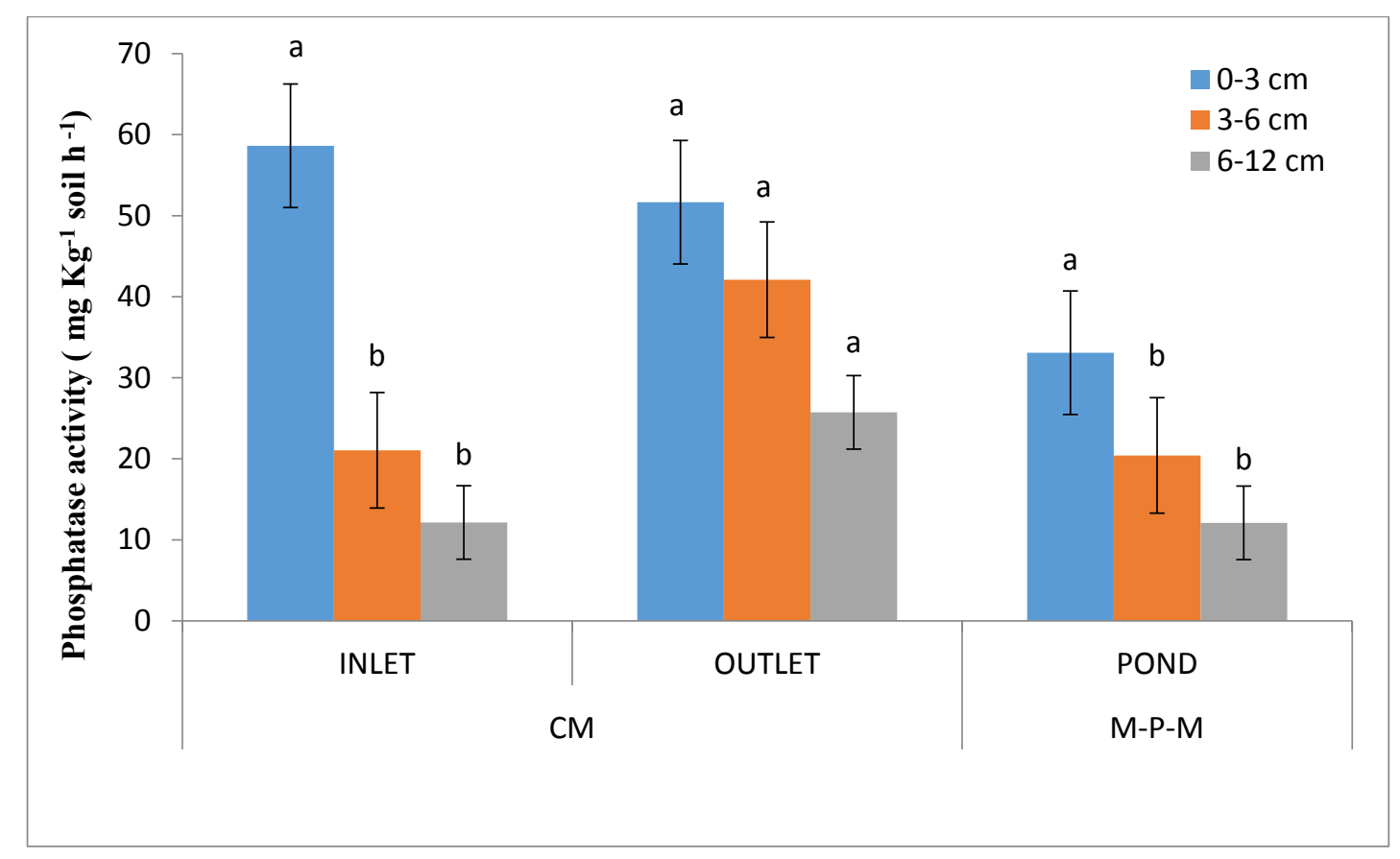

Fig. 3. Phosphatase activity at different soil depths in the Continuous marsh (CM) and pond area of Marsh pond marsh (MPM) constructed wetlands (mean $\pm \mathrm{SE}, \mathrm{n}=4$ ).

Note: Means having the same letters in common are not significantly different at the 5\% level of probability for each site at different soil depths of CM and MPM as determined from t-test pair comparison.

\section{4. $\beta$-glucosidase activity}


Increased $\beta$-glucosidase activity was observed at 0-3 $\mathrm{cm}$ depth in CM and MPM (Fig 4). Decreased enzymatic activity was observed with increasing depths in both wetland systems, and the difference was not significant $(P<0.05)$. The enzyme activity was significantly $(P<0.05)$ higher in $\mathrm{CM}$ compared to pond area of MPM wetland. In $\mathrm{CM}$, the activity of $\beta$-glucosidase was not significantly different between inlet and outlet areas (Table 2).

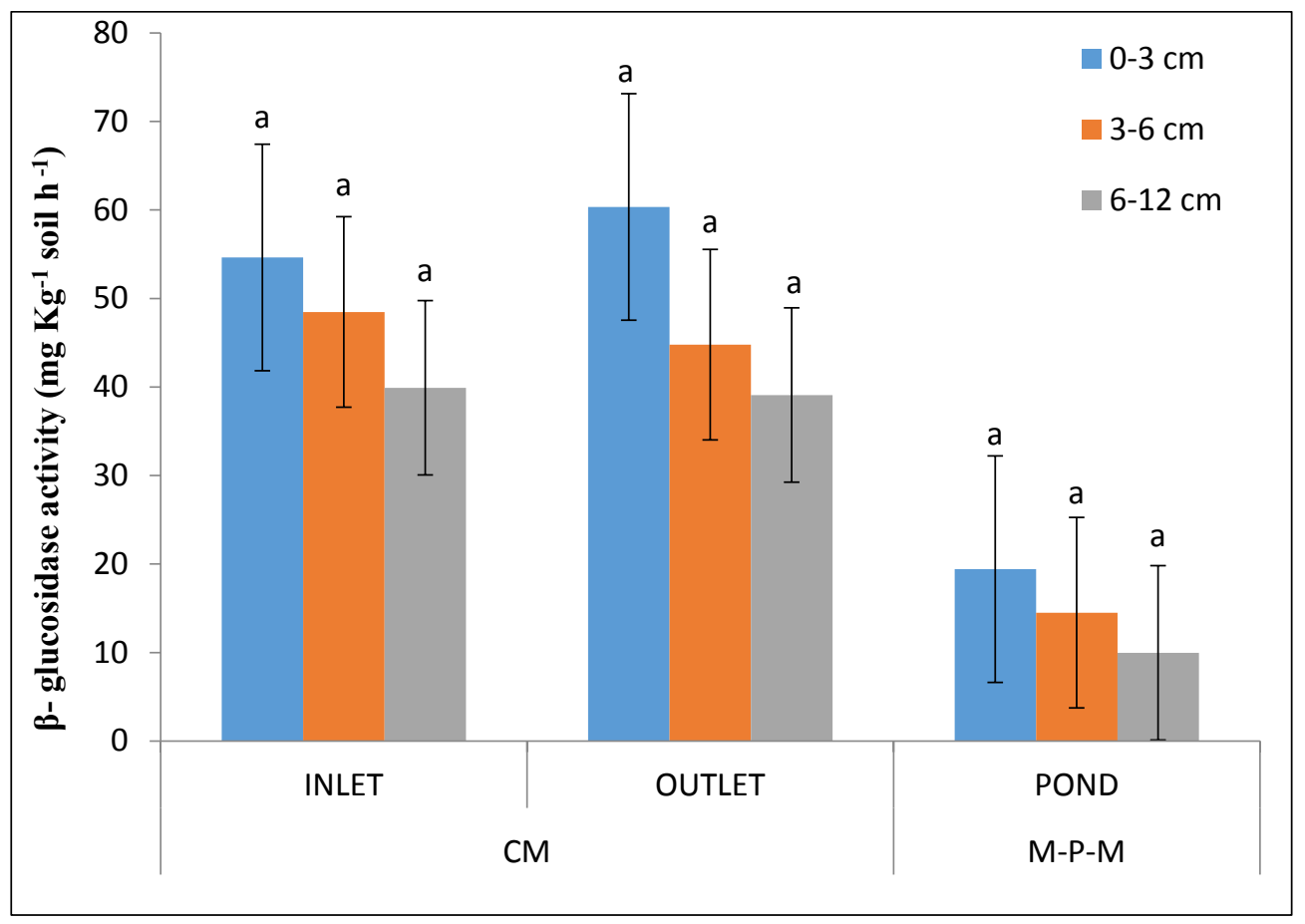

Fig. 4. $\beta$-glucosidase activity at different soil depths in the Continuous marsh (CM) and pond area of Marsh pond marsh (MPM) constructed wetlands (mean \pm SE, $n=4)$.

Note: Means having the same letters in common are not significantly different at the 5\% level of probability for each site at different soil depths of CM and MPM as determined from t-test pair comparison. 


\subsection{Dehydrogenase activity}

In CM and MPM, dehydrogenase activity decreased with the depth of the wetland (Fig 5). In CM, enzyme activity decreased from inlet to outlet showing no significant difference among distance in wetland (Table 2). Dehydrogenase activity was significantly $(P<0.05)$ higher in $\mathrm{CM}$ as compared to the pond area of MPM.

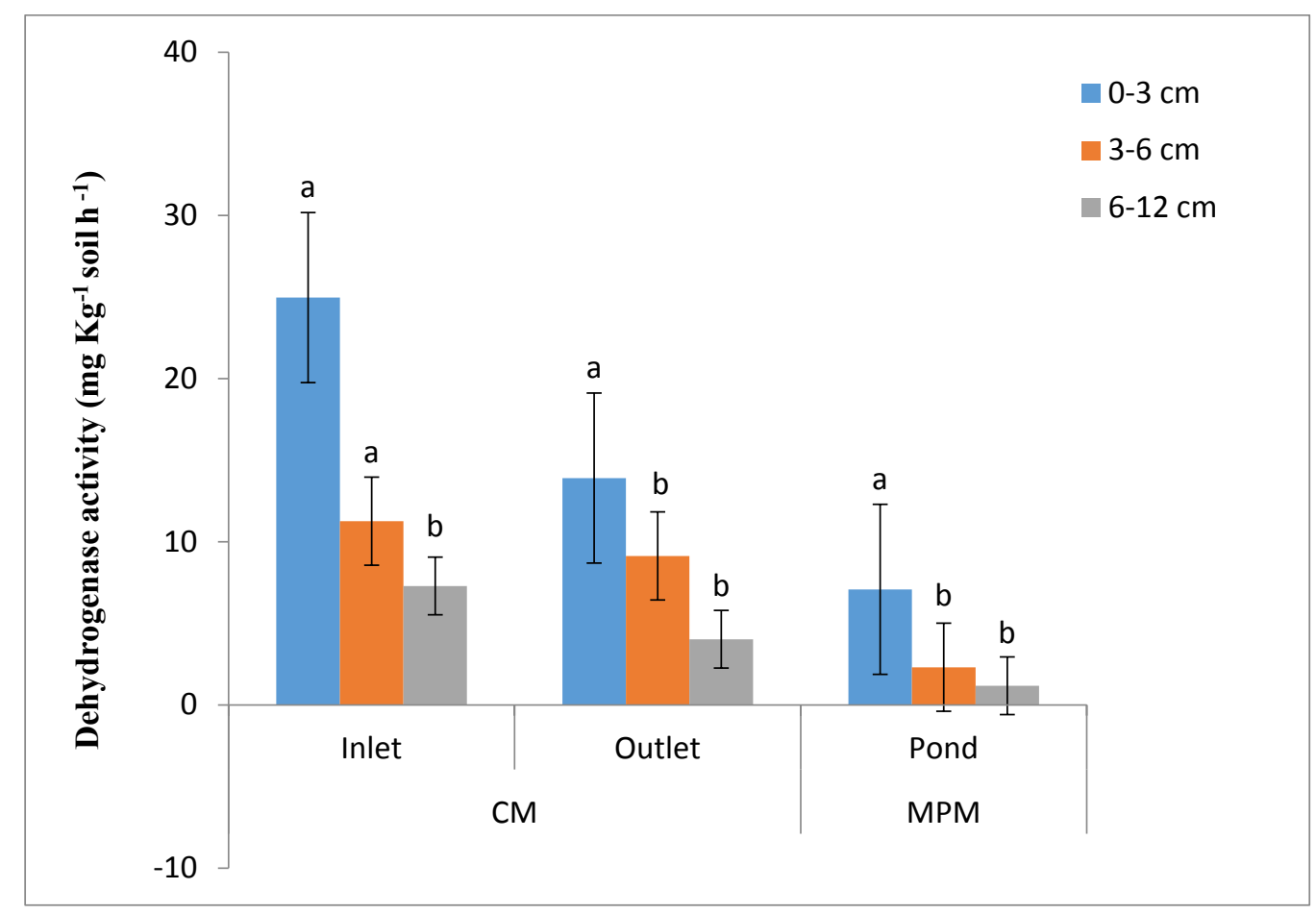


Fig. 5. Dehydrogenase activity in each site at different soil depths in the Continuous marsh (CM) and pond area of Marsh pond marsh (MPM) constructed wetlands (mean \pm $\mathrm{SE}, \mathrm{n}=4)$.

Note: Means having the same letters in common are not significantly different at the 5\% level of probability for each site at different soil depths of CM and MPM as determined from t-test pair comparison.

\subsection{Microbial Biomass Carbon (MBC)}

Microbial biomass carbon was higher at $0-3 \mathrm{~cm}$ depth in CM and pond area of MPM (Table 3). In both the wetlands, MBC decreased with depth and no significant $(P<0.05)$ difference was found among the depths. Microbial biomass carbon was higher in marsh areas of CM compared to pond area of MPM and the difference was significant $(P<0.05)$ among them. In $\mathrm{CM}, \mathrm{MBC}$ decreased from inlet to outlet at all three depths and the difference between them was not significant. Biomass $\mathrm{C}$ was in the range of 5$7 \%$ of total $\mathrm{C}$ in each depth.

\section{Table 3}

Microbial Biomass Carbon (MBC) values at three different depths in CM and pond area of MPM.

\begin{tabular}{llll}
\hline \multirow{2}{*}{ Site } & \multicolumn{2}{l}{ Microbial Biomass Carbon $\left(\mathrm{mg} \mathrm{Kg}^{-1} \mathrm{soil}\right)$} \\
\cline { 2 - 3 } & $\mathbf{0 - 3 \mathrm { cm }}$ & $\mathbf{3 - 6} \mathrm{cm}$ & $\mathbf{6 - 1 2} \mathrm{cm}$ \\
\hline
\end{tabular}




\begin{tabular}{lccc}
\hline CM Inlet & 712.1 & 625.2 & 408.6 \\
\hline CM Outlet & 660.7 & 502.0 & 425.3 \\
\hline MPM (Pond) & 364.7 & 336.6 & 289.8 \\
\hline
\end{tabular}

\subsection{Correlation between enzyme activity and nutrient concentration}

The relationship between urease activity to $\mathrm{NH}_{4}{ }^{+}$concentration and phosphatase activity to $\mathrm{PO}_{4}{ }^{-}$concentration in $\mathrm{CM}$ and MPM at different depths were determined by linear correlation analysis. No significant $(P<0.05)$ correlation between urease activity and $\mathrm{NH}_{4}{ }^{+}$concentration, and phosphatase activity and $\mathrm{PO}_{4}{ }^{-}$concentration were found in $\mathrm{CM}$ and MPM at all three depths.

\subsection{Correlation between enzyme activity and TC and TN}

Urease, $\beta$ glucosidase, dehydrogenase, and phosphatase activities were significantly $(<0.01)$ correlated to TC and TN at $0-3 \mathrm{~cm}$ depth in both $\mathrm{CW}$ systems (Table 4 and 5) except for hydrogenase in pond area of MPM. All the enzymes activities were not significantly correlated to TC and TN at $6-12 \mathrm{~cm}$ depth in both $\mathrm{CM}$ and pond area of MPM (Tables 4 and 5). The results indicate that these enzymes activities are dependent on the availability of TC and TN in soil.

\section{Table 4}


Correlation coefficients between soil enzyme activity and TC and TN at three different depths in Continuous marsh wetland.

\begin{tabular}{lllllllll}
\hline Enzymes & \multicolumn{3}{c}{ Total C $\dagger$} & & \multicolumn{3}{c}{ Total N $\dagger$} \\
\cline { 2 - 4 } \cline { 7 - 8 } & $\mathbf{0 - 3} \mathbf{~ c m}$ & $\mathbf{3 - 6} \mathbf{~ c m}$ & $\mathbf{6 - 1 2} \mathbf{~ c m}$ & & $\mathbf{0 - 3} \mathbf{~ c m}$ & $\mathbf{3 - 6} \mathbf{~ c m}$ & $\mathbf{6 - 1 2} \mathbf{~ c m}$ \\
\hline Urease & $0.92^{* *}$ & $0.69^{* *}$ & $0.40^{\mathrm{NS}}$ & & $0.95^{* *}$ & $0.80^{* *}$ & $0.51^{\mathrm{NS}}$ \\
Phosphatase & $0.75^{* *}$ & $0.46^{\mathrm{NS}}$ & $0.18^{\mathrm{NS}}$ & & $0.71^{* *}$ & $0.33^{\mathrm{NS}}$ & $0.13^{\mathrm{NS}}$ \\
$\beta$-glucosidase & $0.71^{* *}$ & $0.58^{*}$ & $0.31^{\mathrm{NS}}$ & & $0.59^{*}$ & $0.49^{\mathrm{NS}}$ & $0.20^{\mathrm{NS}}$ \\
Dehydrogenase & $0.63^{*}$ & $0.39^{\mathrm{NS}}$ & $0.14^{\mathrm{NS}}$ & & $0.80^{* *}$ & $0.58^{*}$ & $0.49^{\mathrm{NS}}$ \\
\hline
\end{tabular}

Note: $\uparrow *$ Represent significant correlations at $p<0.05$.

** Represent significant correlations at $p<0.01$.

NS Represent no significant correlations at $p<0.05$.

\section{Table 5}

Correlation coefficients between soil enzyme activity and TC and TN at three different depths in pond area of MPM wetland

\begin{tabular}{|c|c|c|c|c|c|c|}
\hline \multirow{2}{*}{ Enzymes } & \multicolumn{3}{|c|}{ Total C $\dagger$} & \multicolumn{3}{|c|}{ Total $\mathbf{N} \dagger$} \\
\hline & $0-3 \mathrm{~cm}$ & $3-6 \mathrm{~cm}$ & $6-12 \mathrm{~cm}$ & $0-3 \mathrm{~cm}$ & $3-6 \mathrm{~cm}$ & $6-12 \mathrm{~cm}$ \\
\hline Urease & $0.97 * *$ & $0.73 * *$ & $0.60^{*}$ & $0.97 * *$ & $0.81 * *$ & $0.75^{* *}$ \\
\hline Phosphatase & $0.95 * *$ & $0.67 *$ & $0.23^{\mathrm{NS}}$ & $0.96 * *$ & $0.58 *$ & $0.22^{\mathrm{NS}}$ \\
\hline$\beta$-glucosidase & $0.67 *$ & $0.60 *$ & $0.52^{\mathrm{NS}}$ & $0.63 *$ & $0.57 *$ & $0.35^{\mathrm{NS}}$ \\
\hline
\end{tabular}


$\begin{array}{lllllll}\text { dehydrogenase } & 0.42^{\text {NS }} & 0.36^{\text {NS }} & 0.21^{\text {NS }} & 0.51^{\text {NS }} & 0.39^{\text {NS }} & 0.26^{\text {NS }}\end{array}$

Note: $\uparrow *$ Represent significant correlations at $p<0.05$.

** Represent significant correlations at $p<0.01$.

NS Represent no significant correlations at $p<0.05$.

\section{Discussion}

Enzyme activities were higher in upper $0-3 \mathrm{~cm}$ depth for all four enzymes in $\mathrm{CM}$ and pond area of MPM wetland systems and their activity decreased with depth. Earlier studies have also reported that activities of enzymes were higher in upper sediment depths (Aon and Colaneri, 2001; Niemi et al., 2005). Factors such as oxygen availability, organic carbon availability, $\mathrm{pH}$ and soil nutrients could influence the soil enzyme activities in wetlands. In these wetlands, swine wastewater first flowed from inlet area to outlet area and surface soil is exposed to nutrients and organic carbon rich wastewater and therefore, could influence the increased rate of microbial growth and enzyme activity in upper $0-3 \mathrm{~cm}$ sediment depth. The decrease in the enzyme activities in deeper layers could be due to the changes in microbial population, decrease in synthesis of enzymes, low organic matter content, and or increase of inhibitors such as metal ions under the reduced condition (Pulford and Tabatabai, 1988; Freeman et al., 1997). For all the enzymes studied, no significant difference in enzymes activities between inlet and outlet of both CM and MPM (Table 2) was observed. This may be due to 10 years long utilization of the $\mathrm{CWs}$ for swine wastewater treatment which could 
have affected the settling of organic matter, nutrient and microbial influx in inlet and outlet areas of both the wetlands.

Increased urease activity was observed in both wetlands and it may be due to the low availability of $\mathrm{NH}_{4}{ }^{+}$in the wetlands because of nitrification process. Previous studies at this site showed $70-95 \%$ nitrogen $(\mathrm{N})$ removal from swine wastewater when the wetland cells were loaded with 3 to $36 \mathrm{~kg} \mathrm{~N} \mathrm{ha}^{-1}$ day $^{-1}$ (Poach et al., 2004; Reddy et al., 2001) and the conclusion was nitrification and denitrification were the desired mechanisms for $\mathrm{N}$ removal, since $\mathrm{N}$ accumulation by wetland plants accounted for less than $10 \%$ of the N load (Reddy et al., 2001; Hunt et al., 2002; Poach et al., 2004). Results were consistent with the urease activities reported by Zhang et al. (2010), wherein they found that, depending upon the species richness in full scale constructed wetlands for the treatment of domestic wastewater, urease activities ranged from 120 to $400 \mathrm{mg} \mathrm{Kg}^{-1}$. Since, larger microbial populations (Dong and Reddy, 2010) require $\mathrm{NH}_{4}{ }^{+}$as a N source and due to the lack of required $\mathrm{NH}_{4}{ }^{+}$concentration, microbes produce urease enzyme to hydrolyze urea, which is present in the swine waste. Treated swine wastewater contains high inorganic phosphate or available phosphorus in the soil (Table 1) which might have decreased the phosphatase activity in these constructed wetlands. This is in agreement with the observations of Reddy et al. (2001) and Poach et al. (2004) who have indicated that only $40-45 \%$ removal of phosphorus $(\mathrm{P})$ from the swine wastewater occurred when these CWs were treated with 3 to $36 \mathrm{~kg} \mathrm{~N}$ per ha $^{-1}$ day $^{-1}$. We observed lower $\beta$-glucosidase activity when compared to other ecosystems. However, Chrost 
(1991) reported that the addition of glucose greatly decreased $\beta$-glucosidase activity, which may indicate substrate inhibition by the addition of low molecular weight carbon. This suggested that the characteristics of organic matter produced by plants and treatment wastewater may be responsible for the increase or decrease of enzyme activity in the constructed wetlands.

The results indicated that all studied enzyme activities were lower in pond area of MPM in comparison to marsh areas of $\mathrm{CM}$ wetland. The presence of plants could influence the changes of enzyme activities in marsh area by supplying organic carbon and modifying hydrochemistry in rhizosphere. Choi et al (2009) reported that the organic carbon supplemented by root exudates, root debris and plant residue played an important role in increasing enzyme activities in the sediments with plants. They also reported sediments with wetland plants exhibited significantly higher enzyme activities of $\beta$-glucosidase, arysulfatase, phosphatase and $\mathrm{N}$-acetylglucosaminidase and observed that organic matter was significantly higher in vegetated than non-vegetated wetlands. The results suggest that the characteristics of $\mathrm{CM}$ wetland are different from the pond area of MPM wetland due to the presence of vegetation.

Microbial biomass is dynamic and sensitive to changes due to the nutrient loading (Powlson and Jenkinson, 1981). Microbial biomass carbon was higher at 0-3 cm depth than in lower soil depths. This data supports higher enzymes activity at 0-3 cm and 
decrease of MBC and enzymes activity with the depths. Also, MBC data supports the differences in enzymes activity between CM and pond area of MPM.

From an ecological point of view, it is believed that an inverse relationship would exist between nutrient availability and enzyme activity (Sinsabaugh et al., 1993). The fundamental relationships between them are repression-depression and end product inhibition of the enzyme (Chrost, 1991). High enzyme activity indicates nutrient limitation (Sinsabaugh et al., 1993), and sometimes a pattern of increasing enzyme activity with decreasing nutrient availability is found in soil. Extracellular enzyme levels are depressed in stream sediments receiving wastewater (Kuhbier, 2002). For example, phosphatase activity increased as P declined (McGill and Cole, 1981) in soil. Activity of the N-releasing enzyme, chitinase increases as $\mathrm{N}$ declines (Olander and Vitousek, 2000) in soil. However, the negative relationship between enzymatic activity and nutrient availability has not been established. There are contradictory reports concerning the relationship between enzymes and inorganic nutrient content in the soil (Spier and Ross, 1978). The inverse relationship between phosphatase activity and soil phosphorus concentration has been shown in several studies (Wright and Reddy, 2001; Allison et al., 2007). On the other hand, urease activity can be limited by high levels of $\mathrm{NH}_{4}{ }^{+}$, a product of the urea hydrolysis (Thorén, 2007). In these CWs (CM and MPM systems), no relationship between urease activity to $\mathrm{NH}_{4}^{+}$concentration and phosphatase activity to $\mathrm{PO}_{4}^{-}$concentration was found. This observation could be attributed to the treated swine wastewater which contained very high autotrophic 
microbial populations (Dong and Reddy, 2010) that demand more $\mathrm{NH}_{4}{ }^{+}$and become competitive to heterotrophs, continuous treatment process where input and output or removal of nutrients occur simultaneously in these wetland systems, and the soil enzymes are largely stabilized by humus and clay, and are thus independent of microbial regulation (Burns, 1982).

The results showed that urease and phosphatase activities were strongly correlated to TC and TN at 0-3 cm depth in CM and pond area of MPM. Urease and phosphatase activities were strongly dependent on the availability of TC and TN. $\beta$-glucosidase activity was significantly correlated with $\mathrm{TC}$ in $\mathrm{CM}$. This suggests that organic matter contain different carbohydrates which have been hydrolyzed into two sugar units and further hydrolyzed by the glucosidase to form glucose units for heterotrophs to consume as their $\mathrm{C}$ source. The results further suggest that $\mathrm{TC}$ and $\mathrm{TN}$ in $\mathrm{CWs}$ influence enzyme activity and decomposition ability.

\section{Conclusions}

Higher enzymatic activity was observed in CM wetland in comparison to MPM wetland. In the present study, various exudates from plants, high inorganic nutrients, microorganisms and total solids from swine wastewater, and detritus seem to contribute to the biogeochemistry of the wetlands. In order for CWs to be efficient, low nutrient loading is required for higher enzyme activity which further enhances nutrients removal capacity of wetlands. This principle is validated by our previous studies (Reddy et al., 
2001; Hunt et al., 2002; Poach et al., 2004) that higher nutrient loading into wetlands reduced the nutrients removal efficiency of wetlands. This suggests that enzyme activity is continuously contributing to the release of inorganic nutrients which may reduce the wetlands efficiency. Even though the enzyme activities were not significantly correlated to nutrient concentrations, it does indicate that the nutrient loads flowing into the wetlands from external sources did not affect the enzymatic activities and contributed to decomposition and perhaps nutrient cycling.

\section{Acknowledgement}

This work was financially supported by the Evans-Allen/USDA-NIFA Grant, NCX259-5-11-130-1. 


\section{References}

Aguilar, J. R. P., Cabriales, J. J. P., Vega, M. M. 2008. Identification and characterization of sulfur-oxidizing bacteria in an artificial wetland that treats wastewater from a tannery, International Journal of Phytoremediation, 10 (5): $359-370$.

Allison, S. D., Vitousen, P.M., 2005. Responses of extracellular enzymes to simple and complex nutrient inputs. Soil Biol. Biochem. 37, 937-944.

Allison, V.J., Condron, L.M., Peltzerc, D.A., S.J. Richardsonc, Turner, B.L., 2007. Changes in enzyme activities and soil microbial community composition along carbon and nutrient gradients at the Franz Josef chronosequence, New Zealand. Soil Biol. Biochem. 39, 1770-1781.

Aon, M.A., Colaneri, A.C., 2001. Temporal and spatial evolution of enzymatic activities and physic-chemical properties in an agricultural soil. Appl. Soil Ecol. $18,255-270$.

Brix, H., 1993. Wastewater treatment in constructed wetlands: System design, removal processes, and treatment performance. Constructed Wetlands for Water Quality Improvement, pp. 9-22.

Burns, R. G., 1982. Enzyme activity in soil: Location and a possible role in microbial ecology. Soil Biology and Biochemistry. 14(5), 423-427. 
Casida, L. E. J., Klein, D. A., Santoro, T., 1964. Soil dehydrogenase activity. Soil Science, 98(6), 371-376.

Choi, H. C., Kang, H., Park, S. S., 2009. Comparison of enzyme activities in vegetated and nonvegetated sediments. Journal of Environmental Engg. 299-305.

Chrost, R. J., 1991. Environmental control of the synthesis and activity of aquatic microbial ectoenzymes. Microbial Enzymes in Aquatic Environments, 29-59.

Dong, X. L., Reddy, G. B., 2010. Soil bacterial communities in constructed wetlands treated with swine wastewater using PCR-DGGE technique. Bioresource Technology 101: 1175-1182.

Duarte, B., Reboreda, R., Cacador, I., 2008. Seasonal variation of extracellular enzymatic activity (EEA) and its influence on metal speciation in a polluted salt marsh. Chemosphere, 73(7), 1056-1063.

Eivazi, F., Tabatabai, M., 1977. Phosphatases in soils. Soil Biology and Biochemistry, $9(3), 167-172$.

Eivazi, F., Tabatabai, M. A., 1988. Glucosidases and galactosidases in soils. Soil Biology and Biochemistry, 20(5), 601-606.

Freeman, C., Maurice, A., Hughes, S., Reynolds, B., Hudson, J. A., 1997. Nitrous oxide emissions and the use of wetlands for water quality amelioration. Environmental Science and Technology, 31(8), 2438-2440. 
Hill, V. R., Pasternak, J. I., Rice, J. M., Marra, M. C., Humenik, F. J., Sobsey, M. D., Szogi, A. A., Hunt, P. G., 1999. Economics of nitrogen and enteric microbe reductions in alternative swine waste treatment techniques. Paper presented at the NCSU Animal waste management symposium, Cary,NC.

Hunt, P. G., Szogi, A. A., Humenik, F. J., Rice, J. M., Matheny, T. A., Stone, K. C., 2002. Constructed wetlands for treatment of swine wastewater from an anaerobic lagoon. Transactions of the ASAE. 45(3), 639-647.

Johnstone, C. A., 1991. Sediment and nutrient retention by freshwater wetlands: Effects on surface water quality. Critical Reviews in Environmental Control (USA).

Kadlec, R., Knight, R., 1996. Treatment Wetlands. Boca Raton, Florida, USA: Lewis Publishers.

Kang, H., Freeman, C., Lee, D., Mitsch, W., 1998. Enzyme activities in constructed wetlands: Implication for water quality amelioration. Hydrobiologia, 368(1), $231-235$.

Klose, S., Tabatabai, M. A., 2000. Urease activity of microbial biomass in soils as affected by cropping systems. Biology and Fertility of Soils, 31(3), 191-199.

Knight, R. L., Payne Jr, V. W. E., Borer, R. E., Clarke Jr, R. A., Pries, J. H., 2000. Constructed wetlands for livestock wastewater management. Ecological Engineering, 15(1-2), 41-55. 
Krasnits, E., Friedler, E., Sabbahb, I., Beliavski, M., Tarrea, S., Green, M., 2009. Spatial distribution of major microbial groups in a well-established constructed wetland treating municipal wastewater. Ecological Engineering 35: 1085-1089.

Kuhbier, S., 2002. Enzymatic response to pollution in sediments and aquatic systems. p. 433-446. In R.G. Burns and R.P. Dick (ed.) Enzymes in the environment: Activity, ecology and applications. Marcel Dekker, New York

Mallin, M., 2000. Impacts of industrial animal production on rivers and estuaries animal-waste lagoons and sprayfields near aquatic environments may significantly degrade water quality and endanger health. Soil Science, 88, 26-37.

McGill, W.B., Cole, C. V., 1981. Comparative aspects of organic C, N, S and P cycling through soil organic matter during pedogenesis. Geoderma, 26, 267-286.

Niemi, R.M., Vepsalainen, M., Wallenius, K., Simpanen, S., Alakukku, L., Pietola, L., 2005. Temporal and soil depth-related variation in soil enzyme activities and in root growth of red clover (Trifolium pratense) and timothy (Phleum pratense) in the field. Appl. Soil Ecol., 30, 113-125.

Olander, L.P., Vitousek, P.M., 2000. Regulation of soil phosphatase and chitinase activity by $\mathrm{N}$ and $\mathrm{P}$ availability. Biogeochemistry, 49, 175-190.

Poach, M.E., Hunt, P.G., Reddy, G.B., Stone, K.C., Johnson, M.H., Grubbs, A., 2004. Swine wastewater treatment by marsh-pond-marsh constructed wetlands under varying nitrogen loads. Ecol. Eng., 23, 165-175. 
Powlson, D.S., Jenkinson, D.S., 1981. A comparison of the organic matter, biomass, adenosine triphosphate and mineralizable nitrogen contents of ploughed and direct-drilled soils. J. Agric. Sci. 97, 713-721.

Pulford, I.D., Tabatabai, M.A., 1988. Effect of waterlogging on enzyme activities in soils. Soil Biology and Biochemistry, 20, 215-219.

Reboreda, R., Cacador, I., 2008. Enzymatic activity in the rhizosphere of Spartina maritima: Potential contribution for phytoremediation of metals. Marine Environmental Research, 65(1), 77-84.

Reddy, G. B., Hunt, P. G., Phillips, R., Stone, K., Grubbs, A., 2001. Treatment of swine wastewater in marsh-pond-marsh constructed wetlands. Water Science and Technology, 44(11-12), 545-550.

Reddy, K. R., DeLaune, R. D., Craft, C. B., 2010. Nutrients in Wetlands: Implications to water quality under changing climatic conditions. Report to U.S. Environmental Protection Agency. EPA Contract No. EP-C-09-001: 1-48.

Sinsabaugh, R.L., Antibus, R.K., Linkins, A.E., McClaugherty C.A., Rayburn, L. D., Repert, T., Weiland, 1993. Wood decomposition: nitrogen and phosphorus dynamics in relation to extracellular enzyme activity. Ecology 74, 1586-1593.

Spier, T.W., Ross, D.J., 1978. Soil phosphatase and sulphatase, R.G. Burns (Ed.), Soil Enzymes, Academic Press, New York, 197-230. 
Tabatabai, M. A., 1982. Methods of soil analysis. Part 2. Chemical and microbiological properties. Madison, WI: American Society of Agronomy, Soil Science Society of America.

Tabatabai, M. A., Bremner, J. M., 1969. Use of p-nitrophenyl phosphate for assay of soil phosphatase activity. Soil Biology and Biochemistry, 1(4), 301-307.

Thorén, A.K., 2007. Urea transformation of wetlands microbial communities. Microbial Ecol. 53, 221-232.

Vance, E.D., Brookes, P.C., Jenkinson, D.S., 1987. An extraction method for measuring soil microbial biomass C. Soil Biol. Biochem. 19, 703-707.

Wetzel, R., G., 1991. Extracellular enzymatic interations: storeage, redistribution, and interspecific communication. In: Chrost R.J. (ed) Microbial enzymes in aquatic environments. Springer-Verlag, New York, 6-28.

Wright, A.L., Reddy, K.R., 2001. Phosphorus loading effects on extracellular enzyme activity in Everglades wetland soils. Soil Sci. Soc. Am. J. 65, 588-595.

Zaman, M., Di, H. J., Cameron, K. C., Frampton, C. M., 1999. Gross nitrogen mineralization and nitrification rates and their relationships to enzyme activities and the soil microbial biomass in soils treated with dairy shed effluent and ammonium fertilizer at different water potentials. Biology and Fertility of Soils, 29(2), 178-186. 
Zhang C. B., Wang, J., Liu, W. L., Xhu, S. X., Ge, H. L., Chang, S. X., 2010. Effects of plant diversity on nutrient retention and enzyme activities in a full-scale constructed wetland. Bioresource Technol. 101, 1686-1692. 